\title{
Challenges Towards Sustainable Tourism for Regional Development of Vlore Region
}

\author{
Aleks Prifti ${ }^{1} \mathrm{PhD}(\mathrm{c})$, Engjellushe Zenelaj ${ }^{1} \mathrm{PhD}(\mathrm{c})$
}

\begin{abstract}
:
Vlora has great potential for regional development. Tourism can be as a catalyst for the economic growth but still have many challenges for sustainable tourism regional development. Regional development is one of the most important dimensions and key of EU policy, which is designed to: ensure convergence between the different member states and regions; ensure regional competitiveness and employment; ensure territorial cooperation. Vlora has all the potential to be an attractive tourism destination. Resources that it can use to create its distinctive image for tourists are numerous. Across geography, which has spread Vlora region, there are monuments, archaeological item and rare natural monuments, natural sites and attractions centuries. Way to understand these apparently already clarified is joining with the tourism environment. Return tourism potential in real estate assets for the rapid development and prosperity of the region, is one of the objectives with which to measure the role of state institutions, businesses, investitures and policies that support, promote, stimulate and develop the sector oh tourism. Tourism development is facing many challenges related to development and the control urbanity, decentralization process, the geographical distribution of tourism, exploitation of all resources and tourist potential, the protection of natural and cultural heritage.
\end{abstract}

Key words: sustainable regional development, sustainable tourism development, decentralization process,

\section{Introduction}

Tourism is not a single activity, but is a collection of very similar activities and includes: transportation, accommodation, food, service, drinks, cultural entertainment, conventions and trade fairs, sport and recreation. Region of Vlora is a dynamic region, based on its assets and opportunities, attractive for businesses to work in partnership with government and the community to create a sustainable and diversified economy. In Vlora region estimated tourism as a key sector for the development of the region, to promote many activities, the creation of jobs and the direct benefit to families and individuals. In this region there are a variety of real natural, cultural, historical and human resources more favorable to develop a diversified tourism.

${ }^{1}$ Lecturer at Ismail Qemali University of Vlore, Albania 
Vlora has two entry ways: by land and sea border crossings. In Vlora, you can achieve through lines departing from the harbor of Brindisi, of Bari etc. Overland tourists should travel to these cities: Tirana-Vora-Durres-Kavaja Lushnje-Fier-Vlora.

Vlora region is located in the south west of the country, around $135 \mathrm{~km}$ from Tirana, $72 \mathrm{~km}$ from Italy and 77 miles away from Greece. Vlora region boundaries length is $273 \mathrm{~km}$ of which 129 are land borders and $144 \mathrm{~km}$ water border. (Sazan Guri, 2007)

Vlora is one of the regions with the largest and length coastline, about $30 \%$ of the total coastal line in the country. Mediterranean features of the landscape, climate and culture are its main feature. In the north, Vlora region, bounded by the region of Fier through Vjosa River, which along with Shushicë River (River of Vlora), constitute the most important source of fresh water. Vlora region does not lack mountainous, as Mount of Çika, 2045m above sea level, Mount of Sevasteri, Mount of Çipini, etc.

Alteration of limestone to granite rocks of alluvium are a typical feature of this area. In inland areas are stunning landscapes, as generations of forest, meadows, streams and caves. Capital of Region is the city of Vlora, with about 140,000 inhabitants. Other cities are: Orikum, Himara, Selenice. Total population of the region is approximately 200,000. (Bashkia Vlorë, 2005)

Vlora is known for favorable Mediterranean climate, where it interacts with the marine climate and the freshness of the sea to the mountains snow. Sea with its impact does not allow maximum temperature increase during the summer and reduction the extreme temperature in winter. The average temperature in winter is about $9{ }^{\circ} \mathrm{C}$, while the July $34^{\circ} \mathrm{C}$. Is recorded an average of 125 sunny days and 77 cloudy days.

Being an early center of civilization to distinguish wealth and variety of cultural and historical monuments as: Castle, museum, characteristic houses, cult monuments, ancient cities, etc..

As a result of all the potential that we highlight four main tourist areas:

1. Areas of sandy shores and lagoon

2. Small beaches

3. Mountainous areas of national parks

4. Rocky areas with scenic landscapes

Depending on all these conditions be they domestic or foreign tourists may very well find yourself in a tourism types as below: geo-monument tourism, sun-sandwater, eco-tourism, agro-tourism, mountain tourism, family tourism, underwater tourism, adventure tourism, ethnographic, religious, sports history, etc.. 


\subsection{Factors that favor tourism and industry}

Vlora has an incredible potential for tourism development. Treatises and analysis of the preceding chapters identified it with the best. A very favorable geographic position with the potential social, demographic, natural, cultural and historical tourism mean that we Vlore to reflect positively from year to year. Geographical space of Vlore meets with the best incentive to tourist demand factors (leisure, environment, etc.) tourism supply factors (tourism resources, natural beauty, attractive activities etc.) and intermediary factors (tourist agencies, tourist transport, tourism policy, promotion tourism).

But on the other hand, there is another type of economic development direction where it comes to the energy industry. There are several reasons and factors that favor the development of this industry in the space of Vlora. So specifically:

1. Coastal zone

2. The deep sea area

3. Favorable climate

4. Demographic and human potential

5. Demand for energy growing ever

The presence of the port plays feature not only for the movement of people but also of the goods and that the dog is an area with considerable depth the possibility that we created marine and heavy tonnage ships anchor which is not possible in ports Other of our country.

Also cannot ignore the demographic potential that serves for the industry. From year to year as a result of natural conditions, geographical position, development level and pace of that has walked the area is dishonored not only a center of population concentration but also economic activities which are being added to increase the demand for energy and a such situations this type of industry would come to the rescue.

Today more and more we hear talked about the concept of sustainable development, and what is the most important accomplishment of its specific effects in space. In order to have a sustainable cooperation or sustainable development it must be a stable relationship between social-businessenvironments. If the ratio between changes or broken up then cannot talk about sustainable development.

\section{First challenges: Tourism or Industry for sustainable regional development}

\section{Can co-exist these two parallel?}

Tourism industry finds suitable conditions to develop in the region of Vlora. Petrol industry that is rising in Vlore conflicts with tourism industry. The reasons are many but we differentiate some of them: 


\section{A population of 12,000 inhabitants located on $0.6 \mathrm{~km}$ radius distance} which means that not dote created buffer zones. The creation of a buffer zone in such a situation is very important because a distance so small and its absence lead to not only curb impact tourism but above all the health of population. (Sazan Guri, 2007)

Wind direction NW-SE coincides wind rose shows the direction of the wind is always toward the city, toward the inhabited area. This mean that all of the base that will be emitted into the atmosphere in its wind direction will be directed towards the space inhabited primarily affecting the health of residents. (Sazan Guri, 2007)

Secondly away tourists because no one likes to visit a contaminated area, and above all hurting area biodiversity as a result of acid rain that will create .

\subsection{Employment Report :Tourism vs Industry}

Construction of industrial park had a period of 2 years and to build it work around 2000 people, but after the construction end, for its operation requires only 100 workers, but on the other hand have tourism which functions as a separate industry.

Vlora has a coastline of $145 \mathrm{~km}$. According to World Bank standards for every $200 \mathrm{~m}$ can construct a hotel, with four floors, which means 5 hotels $1 \mathrm{~km}$ length. Computations Vlora coastline the number of hotels goes in 700.1 hotels hotel has 120 beds, which means that can accommodate 84000. A tourist bed employs four individuals directly and indirectly and based on the number of hotels and bed calculations to derive the conclusion that for 5 months employed 300,000 individuals. Summer-winter difference is in the ratio 1:4, or 75000 workers in the winter season.

Not for nothing is presenting this analysis because the aim is clearly: to identify who has more social and economic impacts. Is simply to understand the importance of tourism and Its clearly because it provides a long-term employment and much more higher than the energy industry.

\section{Challenges of decentralization}

Also tourism is an industry where, after the business has started, the income can be derived relatively quickly and in other economic activities. On the other hand, tourism is a sector extremely vulnerable to external shocks from economic, environmental or political situations. But tourism has also negative effects. Developing countries should draw a lesson that tourism must be managed carefully if he should contribute to the creation of new jobs and income and play a role in eliminating poverty, without prejudice to the local economy, environment, traditions and cultural resources. 
Lack of enforcement of planning legislation and other local normative acts, mismanagement of public property and the lack of registration, etc. are some of the key problems in the development of sustainable tourism in the region of Vlora. Process has seen as great opportunity for not only sustainable tourism development, but also for sustainable development in the whole Vlora region. Tourism development in Albania faces a number of challenges. These are general tourism development challenges faced by all countries entering the international markets as well as specific challenges related to the creation of successful tourism, nature-based destinations and cultures

In the context of decentralization reform development, in terms of transfer functions, responsibilities and powers from the central government, local government units, in contemporary settings, Albania has signed the European Charter of Local Self-Government and ratified it by Law No.8548, dated 11.11.1999 "On the Ratification of the European Charter of Local Autonomy." also adopted legislation on decentralization is consistent with the principles and spirit of this card (QShKE, 2006).

In order to "materialize" political decentralization reform in a single strategic document in 1999 was prepared draft National Decentralization Strategy, which was approved in early 2000. This document was followed by the drafting of the Action Plan, the respective priorities. To coordinate the implementation of this strategy, giving a great importance to the process, in 1999, the Local Government Secretariat was restructured and was created so the Ministry of Local Government and Decentralization.

\section{Territory management}

Transformation of the system in Albania, crossing the country to a market economy and the consolidation of democracy, was followed by a series of numerous complex problems, social, and economic, especially with regard to the system of ownership, use of unplanned and uncontrolled land but the lack of state capacity to plan, develop and exercise control over the territory effectively etc.. .

The rapid development of the informality of the territory could not precede an appropriate institutional and legal framework or the plans or strategies effective regional development and spatial planning, integrated financial and fiscal policy. In fact this is a phenomenon that has been extended in all regions of Albania, but in Vlore clearly evidenced after consequences and effects that in many cases it is impossible to correct. Illegal buildings which took a considerable part of the entire coastline of the region is very difficult to turn the region's natural tourist values.

Today, informal construction, with serious injuries current use of the area (urban 
and rural areas) is distributed as a phenomenon in almost all the region of Vlora, being greater in urban areas; with greater focus and more significantly in their suburban areas. In general developments in urban areas are not good as they have at least two problems:

- First of all we have to do with individual developments, which means that are unplanned, harmonized and built as an urban unit development.

- Second lacks harmonization in certain areas and between types of development itself, or otherwise known as land use types.

To date, 364 local government units in the entire country, or about $98 \%$ of them have completed the inventory list (first phase), while the 224 local government units or about $60 \%$ completed the second stage (approval of the preliminary list) . However, only 123 local unit's government included some of Vlora Region local units, or about 33\% received a decision of the Council of Ministers Decision for the final transfer of assets required in ownership or use (Xhaferri, 2012) . In fact, it shows the progress of the solution of property conflict but also for fixing the central government and local governments. All this inventory process for local government units first is a legal obligation under the decentralization process; is an obligation for local governments but significantly affects regional development, and this inventory process properties achieved in cooperation with other implantations agencies of law as may be Property Restitution and Compensation Agency, Agency for Legislation and Urbanization Informal Areas (ALUIZNI), offices of Local Agencies for property registration. In the context of sustainable development by the Albanian by the government which took shape with the decision in parliament changed the whole legal framework of administration and management of the territory of the Republic of Albania. According to the old Law, local government was full power for management and planning of territorial space. With the approval of the new law on "Planning of the territory of the Republic of Albania", a combination of the competencies of the jurisdiction of local and central government, but also the intermediate from the legal perspective of establishing a good protection for the use and management of the territory, because it combined several bodies who should be in complete unanimity to determine the destination of the use of the territory.

\section{Tourism law}

Tourism was considered only after the 1990s economic activity in the country. Law no. 7665, dated 21.01.1993, "On the development of areas with potential for tourism" was first law on tourism in Albania. This law is aimed at promoting investment in tourism development priority areas, which are defined by Decision Nr. 88, dated 01.03.1993 "On approval of tourism development 
priority zones" through the creation of concepts "Promoted person", "stimulating activities" and "stimulated area." Among the main drivers for investment in tourism development priority areas which have acted in accordance with this law listed: To use through the state-owned areas of the lease agreement with the institution; fiscal facilities has stimulated person subject to the exercise of this activity. Tourism law since its first approval so far has changed several times, as a result of the need to comply with sustainable regional development. Recently is approved by the Parliament a new law "For Tourism" Nr.9374, dated 14.05.2007. The advantage of this law lies in the fact that it was the result of an extensive consultation process conducted with all stakeholders in several workshops. All identified problems have been subject to solution in this project. Tourist business, in this context was presented a draft law parallel, perspective and the perspective of its development interests. The law aims at decentralization and public participation in decision-making processes for tourism at all levels. It promotes nature and natural resources management, facilitates the involvement of the private sector and local communities in sustainable tourism development, and establishes the rights of domestic and foreign tourists, protecting the rights of current sector. Law business tourism has arranged largely competences of local authorities, giving them opportunities for development and management of tourism.

\section{Human recourses and professional qualification}

One of the most serious problems that become an obstacle for tourism in Albania is human resources in the level of employees in the service sector. If the supply of human resources in these services is great, it lacks quality, due to non-recognition of the services sector in tourism, as well as lack of training, contemporary curricula for tourism university system schools and university, as well as entrepreneurs or managers to maintain high level of services, to customer satisfaction and increase the value of the service.

People (workers and entrepreneurs) realize the difference. They are the most valuable in order to satisfy the requirements of the email (tourists). Only welltrained entrepreneurs who raise attractive structure and train skilled personnel, who are service oriented and who want to be responsible for their actions, will be able to satisfy the growing demands of domestic and international tourists. Vlora region from year to year has increased the performance of tourism employees. Employee occupational qualification relates to tertiary education in several areas, such as tourism, foreign languages, marketing, management, etc.. The presence of the university, in the region of Vlora encourage young people to study in the branches of tourism but also graduate to other types of studies because in this way meet the needs of the market, but at the same time increase 
tourism performance. However entrepreneurs, have to pay more attention to training their staff. Although this, region of Vlora has a demographic structure that prevails age, what adds to the possibility of providing tourist services. Youth education creates the possibility for values recognition and assessment of recourses that stalk in their region. In this way can avoid migration of youth age, because they can choose to stay there by investing in tourism enterprises SME. The level presence of tourism SME-s increases the possibility of social and Economic Benefits, Such as Employment and Career, and become Incentives for opening Other Enterprises, expanding the range of the market, because SME-s are a Strategic engine for the Entire tourism Economy (Zenelaj, 2012).

\section{Conclusions}

Vlora has a very favorable geographical position and a large sum of natural and cultural assets. Tourism is the economic future seen for the region developing. Tourism industry is a promoter of sustainable development but it will bring better management and stewardship that have appropriate effects and provide a long-term development, canned and preserved natural and cultural resources. Tourism development will help in employment and total income per destination; accelerated social and economic development throughout the destination; Improvement of living conditions at the destination; beginning of economic activities; Creating a positive international image of the country as tourist destination; increase foreign currency income and tax revenues for the government; social tourism development, and sustainable environment. However the challenges that face in front of sustainable regional development are numerous like Control of the territory, territory management, and territory regulation. County of Vlora Region should develop a research project for the Region of Vlora, anticipating the development of the region for a long period of time. From this research project will emerge that will have regional needs in the future, which should be made public, in order to attract foreign investors

\section{References}

Bashkia Vlorë, V. M. (2005). “Guidë Vlora 2005”, Vlore. Hanxhari ,R.,Guri,S. Vlora dhe R-AMBOT GJEOPOLITIKAT MBI TË”' Tiranë 2007

QShKE, Q. S. (2006). Manual "Menaxhimi i problemeve mjedisore ne nivel vendore ne ",Tirana

Xhaferri, G. (2012). Plani i Menaxbimit te pronave te njesive vendore, Tirane

Zenelaj, E. (2012). Toruism entrepreneurships, Germany: Lap Lambert Academic Publish 